\title{
ジュール熱溶接による熱電回路の作製と高効率化のための試み Fabrication of Thermoelectric Circuit by Joule Heat Welding and Some Approaches to Enhance the Generation Efficiency
}

\author{
○学 渡邊 涁仁（東北大） 正 燈明 泰成（東北大）
}

Akihito WATANABE, Tohoku University, Aoba 6-6-01, Aramaki, Aoba-ku, Sendai Hironori TOHMYOH, Tohoku University

Key words : Joule Heat Welding, Bi-Metal Joints, Thermoelectric Circuit, Optimum Length, Efficiency

\section{1.}

近年，太陽光や風力といった再生可能な自然エネルギー の利用が増加している. 中でも工場や家電等の廃熱を利用 した熱発電がクリーンなエネルギーの創出方法として期待 されている. 熱発電には熱電変換現象の一つであるゼーべ ック効果を用いる.物質に温度差 $\Delta T$ を与えると高温側から 低温側へのキャリアの移動が生じる.これによって物質に 熱起電力 $\Delta V$ が発生する現象がゼーベック効果である.より 大きな $\Delta V$ を得るためには, 高い熱電能力有する材料の利用 や，回路内に大きな $\Delta T$ を発生させる必要がある.

前者に関して, 高い熱電能を有する $\mathrm{Bi}_{2} \mathrm{Te}_{3}{ }^{\left[{ }^{[}\right]}$などを使用 した熱電デバイスが開発されている. また, $\mathrm{SiO}_{2}$ ナノワイ ヤの巨大な熱電能が発見されるなど[2], 微細材料を用いて 熱電変換効率が向上できる可能性がある. 後者の $\Delta T$ の増大 に関して，微細材料を用いた場合は省スペース化等の観点 からデバイス内に低温部を確保することが難しく，これを いかに実現するかが重要となってくる，そのために低温部 を作り出寸様々な手法が検討されている ${ }^{[3]}$.

ところで微細材料の利用においては，ボトムアップでの 組み立て技術の一つである溶接技術が必要不可欠である. 提案されている様々な微細材料の溶接手法の中でも, 材料 に電流を付与した際に材料同士の接触点で発生するジュー ル熱を利用した溶接手法は，大型の装置を必要とせず, 定直流電流の付与下で溶融から凝固までが自己完了できる といったデバイス作製時の様々な利点がある ${ }^{[4]}$.

そこで本研究では, 直径 $100 \mu \mathrm{m}$ の $\mathrm{Fe}, \mathrm{Al}$ マイクロ細線 を用いて，異種金属細線のジュール熱溶接条件を見出すと 共にこの手法を用いて熱電回路を作製することを目的と する. 細線長さを変更する回路内の Thermal management に よって当該回路の発電効率が向上できることを示す.

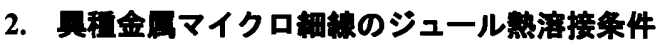

ジュール熱溶接は一定直流電流 $I$ の付与下で溶接が自己 完了する手法であり ${ }^{[3]}$ ，溶接の可否は $I$ に依存する．そこ で本研究では直径 $100 \mu \mathrm{m}$ の $\mathrm{Fe}, \mathrm{Al}$ マイク口細線の切断お よび溶接実験を行った.これらはコモンメタルであり，原 子拡散現象を利用したナノワイヤ作製事例も報告されてい $ろ^{[5]}$. 実験回路の模式図を図 1 に示す。切断実験では $I$ を 上昇させ, 溶断した時の $I$ を切断電流值 $I_{\mathrm{C}}$ とした．溶接害 験では $I$ を付与した後に溶接の可否を溶接部に力を作用さ せることで確認した．また，溶接完了後も細線が切断され るまでIを増大させた。

実験より得られた通電区間の長さ $l_{0}$ と $I$ との関係を図 2(a), 溶接部の走查型電子顕微鏡 (SEM) 像を図 2(b)に示す。 図 1 より溶接成功の下限電流值は $\mathrm{Fe}$ マイク口細線の切断電 流值の約 70\%であることがわかる.これは過去の Pt 極細線 のジュール熱溶接における事実と一致している ${ }^{[4]}$.また， 溶接成功の上限電流值が $\mathrm{Fe}$ マイク口細線の切断電流值と ほぼ同じであり，溶接後の切断位置が $\mathrm{Fe}$ 側であったことよ り, $\mathrm{Fe}, \mathrm{Al}$ マイクロ細線のジュール熱溶接では Fe の溶融 現象が支配的である.一方, $\mathrm{Fe}$ と $\mathrm{Al}$ の融点はそれぞれ 1813， $933 \mathrm{~K}$ であり，Fe の融点の方が高い.
$\mathrm{Fe}$ と $\mathrm{Al}$ の単位体積当たりの熱容量はそれぞれ $3.53 \times 10^{6}$, $2.43 \times 10^{6} \mathrm{~J} / \mathrm{m}^{3} / \mathrm{K}$ であり，両者の值はほぼ同程度である。こ れより両細線に同等なジュール熱が加えられた際の温度上 昇はほぼ同等であると考えられる．そこで $\mathrm{Fe}$ と $\mathrm{Al}$ のジュ ール熱について考える.I を付与した際にマイクロ細線で 発生するジュール熱は $I$ とマイクロ細線の電気伝導率に依 存する. $\mathrm{Al}$ の電気伝導率は $\mathrm{Fe}$ の約 3.7 倍であり, 同じ $I$ の付与下において $\mathrm{Fe}$ マイクロ細線は $\mathrm{Al}$ マイクロ細線に比 ベて約 3.7 倍のジュール熱を発生させる. 次に熱の逃げに ついて考える. 本実験は大気中にて行っているため, ジュ 一ル熱は大気へ放熱したり，通電プローブへの伝熱するた め，全てが細線の温度上昇に消費されるわけではない，Al の熱伝導率が $\mathrm{Fe}$ のそれの約 3 倍であることから， $\mathrm{Al}$ マイ クロ細線の方が $\mathrm{Fe}$ よりも大きなジュール熱損失があると 考えられ，温度上昇しづらいと考えられる.これらのこと から, Fe, Al マイクロ細線の溶接条件は融点だけではなく, 材料の電気的・熱的特性に大きく依存することがわかる.

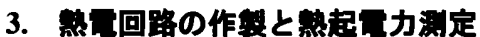

3.1周所的加薙手法 ジュール熱溶接手法を用いて図 3(a)に示すような熱電回路を作製した。異種金属接合部を 局所的な高温部とするために，金属細線のジュール発熱を 利用したヒータワイヤを用いた。金属細線に $I$ を付与した 際, 細線は中央部で最大温度 $T_{\mathrm{H}}$ となり，以下で表すことが できる ${ }^{[6]}$.

$$
T_{\mathrm{H}}=\frac{1}{8 K \sigma}\left(I \frac{l_{0}}{A} f\right)^{2}+T_{0}
$$
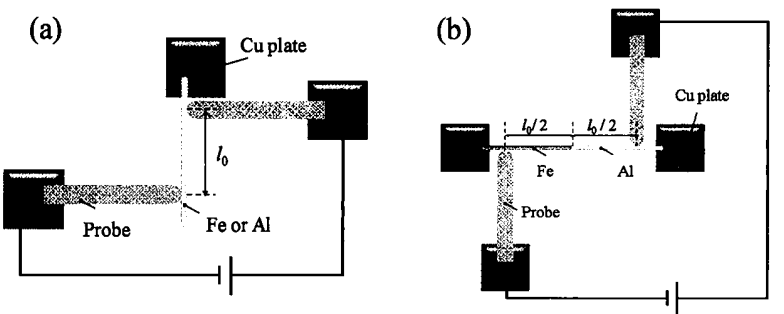

Fig.1 (a) Schematic of cutting microwires. (b) Schematic of welding microwires.

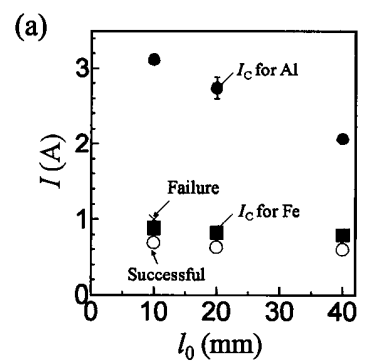

(b)

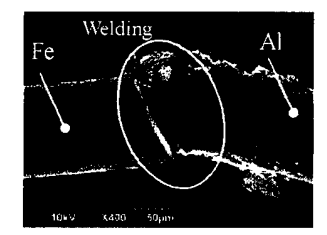

Fig.2 (a) Relationships between $I$ for welding and $l_{0}$. (b) SEM micrograph of weld. 
(a)

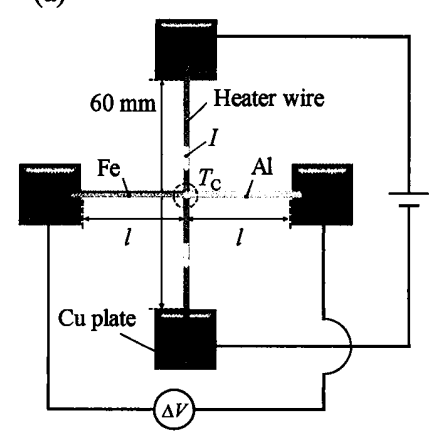

(b)

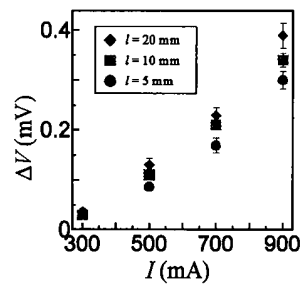

(c)

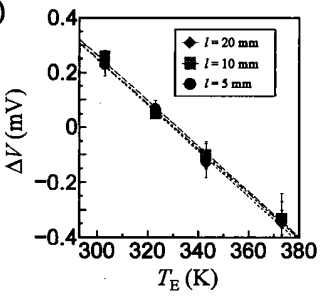

Fig.3 (a) Thermoelectric circuit by joining $\mathrm{Fe}$ and $\mathrm{Al}$ microwires using Joule heat. (b) Relationships between $\Delta V$ and $I$ for various lengths of $\mathrm{Fe}$ and $\mathrm{Al}$ microwires. (c) Relationships between $\Delta V$ and $T_{\mathrm{E}}$.

ここで, $K$ は熱伝導率, $\sigma$ は電気伝導率, $A$ は細線断面積, $f$ は熱的境界条件を補正する関数, $T_{0}$ は雾囲気温度である. 本研究では長さ $60 \mathrm{~mm}$ のヒータワイヤを使用し, 実験によ り求めた $f$ の值は 0.42 であった. ヒータワイヤに付与する $I$ を制御することで, 接合部温度 $T_{\mathrm{C}}$ の温度制御を行った. ここでヒータワイヤの接触による熱的損失を考虑すると $T_{\mathrm{H}}$ と $T_{\mathrm{C}}$ は必ずしも一致しない. そこで熱的結合係数 $C$ を 導入し， $T_{\mathrm{C}}$ が以下のように表せると考えた。

$$
T_{\mathrm{C}}=T_{\mathrm{H}} C+T_{0}(1-C)
$$

3.2 热起而力とゼーベック保数测定 回路路内の Thermal managementを細線長さによって行うために, $l=5,10,20$ $\mathrm{mm}$ において発生する $\Delta V$ を測定した. $I$ と $\Delta V$ との関係を図 3(b)に示す. 図より $l$ が大きい程, 発生する $\Delta V$ は大きくな

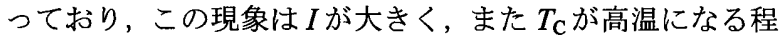
顕著である. 本研究で回路作製に用いた溶接手法，および 細線の種類が同一であったことから，回路のゼーベック係 数 $S$ は $l$ によらず一定であると考えられる．また $T_{\mathrm{C}}$ がヒー タワイヤによって一定に保たれていることから，lによっ て細線端部温度 $T_{\mathrm{E}}$ が変化したものと考えられる.この結果 より，効率的な熱発電のためには $l$ を増大させれば良いと いえる. しかしながら，l を増大させることで回路サイズ が増大してしまう．そのため，最少の長さで回路内に最大 の温度勾配を発生させることのできる適切な回路長さを選 定する必要がある.このために回路のゼーベック倸数を測 定すると共に，回路の温度勾配について考える。

$S$ の測定には回路内の $\Delta T$ を制御する必要があることから， 端部をセラミックヒータで加熱し $T_{\mathrm{E}}$ を制御した. また, ヒ 一タワイヤには $I=900 \mathrm{~mA}$ を付与し， $T_{\mathrm{C}}$ を一定に保った. $T_{\mathrm{E}}$ と $\Delta V$ の関係を図 3(c)に示す。これより $l$ によって $\Delta V$ が ほぼ変化していないことがわかり, $\Delta V$ が制御できているこ とがわかる．この時の $S$ は以式で表される.

$$
S=-\frac{\Delta V_{1}-\Delta V_{2}}{T_{\mathrm{E} 1}-T_{\mathrm{E} 2}}
$$

ここで添え字は，任意の点 $1 ， 2$ における $\Delta V$ と $T_{\mathrm{E}}$ である. 式(1)より図 3 は直線で近似することができ，その傾きが $S$ である.これより $S=8.4 \mu \mathrm{V} / \mathrm{K}$ と算出された．また $\Delta V=0$ となる時は $\Delta T=0$ と考えられ, $T_{\mathrm{E}}=T_{\mathrm{C}}=333 \mathrm{~K}$ とわかる. この結果より $C=0.32$ とわかり，任意の $I$ の付与下におけ る $T_{\mathrm{C}}$ を導出することが可能となった.
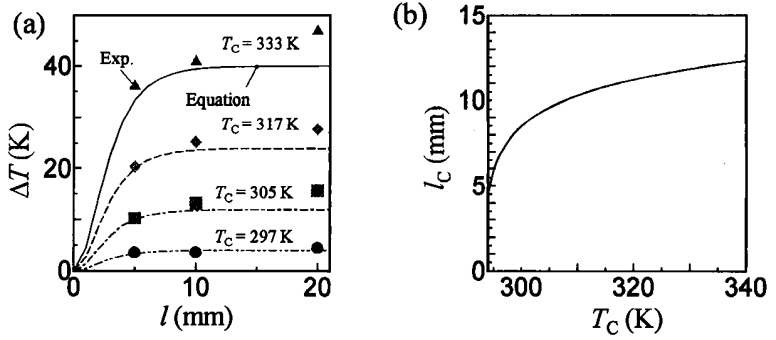

Fig.4 (a) Variations of $\Delta T$ against $l$ for each $T_{\mathrm{C}}$. (b) Relationships between $l_{\mathrm{C}}$ and $T_{\mathrm{C}}$.

\section{4. 最道回路長}

実験結果を基に一元熱伝導モデルを作成することで, 最適 な回路長の選定手法を考案する. Fe と $\mathrm{Al}$ のゼーベック 係数を比較すると $\mathrm{Fe}$ の方が約 10 倍大きいことから, 当該 回路においては Fe の温度勾配が重要であるといえる.そこ で $\mathrm{Fe}$ 細線に関して以下に示す定常状態の一次元熱伝導方 程式を考える.

$$
K \frac{\partial^{2} T}{\partial x^{2}}-\frac{h p}{A}\left(T-T_{0}\right)=0
$$

ここで, $h$ は熱伝達率, $p$ は周囲長さである. 本研究では $h$ $=500 \mathrm{~W} /\left(\mathrm{m}^{2} \mathrm{~K}\right)$ とした. ヒータワイヤ接触部を $x=0, T=T_{\mathrm{C}}$, $\mathrm{Fe}$ マイクロ細線端部を $x=l, \partial T / \partial x=0$ の境界条件下で解 き, 回路内の $\Delta T$ を導出する.

$$
\Delta T=\left(T_{\mathrm{C}}-T_{0}\right) \cdot\left(1-\frac{2}{e^{\lambda l}+e^{-\lambda l}}\right)
$$

ここで $\lambda^{2}=h p / K A$ である.この計算結果と，実験により得 た各 $T_{\mathrm{C}}$ における $\Delta T$ と $l$ との関係を図 4(a)に示す. 図より $\Delta T$ があるlにて飽和する傾向がみて取れる。この飽和し始 める長さを最適回路長 $l_{\mathrm{C}}$ と考え, これを求む. $\Delta T$ を $l$ で偏 微分した $\partial(\Delta T) / \partial l$ がある值 $W$ よりも小さくなる時の $l$ を $l_{\mathrm{C}}$ とすれば,

$$
l_{\mathrm{C}}=\frac{1}{\lambda} \cosh ^{-1}\left(\sqrt{\frac{1+\sqrt{1-4 g}}{2 g}}\right)
$$

ここで $g=\left(W / T_{\mathrm{C}}-T_{\mathrm{E}}\right)^{2}$ である. 本研究では $W=0.1 \mathrm{~K} / \mathrm{mm}$ として導出した $l_{\mathrm{C}}$ を図 4(b)に示す.これより， $T_{\mathrm{C}}$ に応じた $l_{\mathrm{C}}$ を算出，選択することが可能となった.

\section{5.}

本研究では, 直径 $100 \mu \mathrm{m}$ の $\mathrm{Fe}, \mathrm{Al}$ マイクロ細線の異種 金属ジュール熱溶接条件をはじめて見出すことに成功した. また，同溶接手法を駆使して微小熱電回路を作製し，当該 回路の熱起電力を測定した.さらに当該回路のゼーベック 係数を算出すると共に一次元熱伝導モデルを作成して高効 率熱発電のための, 高温部温度に応じた最適な細線長さ設 計指針を提案した。

本研究の遂行に際し，有益なご討論を賜りました東北大 学 坂真澄教授に感謝の意を表します.また本研究が科学研 究費補助金 若手研究 $(A) 24686016$ によったことを記し, 謝意を表します。

\section{者孝文背}

[1] S.A. Whalen, C.A. Apblett \& T.L. Aselage, J. Power Sources, 180 (2008) 657 [2] A.I. Boukai, Y. Bunimovich, J. Tahir-Kheli, J. Yu, W.A. Goddard W \& J.R Heath, Nature, 451 (2008) 168.

[3] J. Yu \& H. Zhao, J. Power Sources, 172 (2007) 428.

[4] H. Tohmyoh \& S. Fukui, Phys. Rev. B, 80 (2009) 155403.

[5] H. Tohmyoh \& A. Watanabe, J. Phys. Soc. Jpn., 82 (2013) 044804

[6] H. Tohmyoh, J. Appl. Phys., 105 (2009) 014907. 